\title{
Analisis Kecemasan Matematika dan Self Efficacy pada E-Learning dalam Kokurikuler SPSS
}

\author{
Mega Kusuma Listyotami \\ ${ }^{1}$ Program Studi Manajemen, Sekolah Tinggi Ilmu Ekonomi Dwi Sakti Baturaja, \\ Jl. Prof. Dr. Hamka No. 541A, Kota Baturaja, Indonesia \\ megakusumalistyotami@gmail.com
}

\begin{abstract}
This study aims to analyze Kecemasan Matematika and student self-efficacy towards E-learning learning in the SPSS (Statistical Product and Service Solutions) crash course co-curricular. The research was conducted with a mixed method with a triangulation design. The research sample was 30 students of the Dwi Sakti Baturaja School of Economics. Data collection techniques using observation, interviews, questionnaires. Mathematical anxiety, student self-efficacy questionnaires, and E learning questionnaires in the SPSS (Statistical Product and Service Solutions) crash course co-curricular. The data analysis techniques used in the study were quantitative and qualitative. The results showed that Kecemasan Matematika and self-efficacy have an effect on E-learning. The relationship between Kecemasan Matematika and self-efficacy on E-learning is 0.938. Kecemasan Matematika and self-efficacy affect E-learning by $87.9 \%$.
\end{abstract}

Keywords: Kecemasan Matematika, Self-efficacy, E-learning

\begin{abstract}
Abstrak
Penelitian ini bertujuan untuk menganalisis kecemasan matematika dan self-efficacy mahasiswa terhadap pembelajaran E-learning dalam kokurikuler crash course SPSS (Statistical Product and Service Solutions). Penelitian dilakukan dengan metode campuran dengan desain triangulasi. Sampel penelitian adalah 30 orang mahasiswa Sekolah Tinggi Ilmu Ekonomi Dwi Sakti Baturaja. Teknik pengumpulan data menggunakan observasi, wawancara, angket kecemasan matematika, angket self-efficacy mahasiswa, dan angket pembelajaran E learning dalam kokurikuler crash course SPSS (Statistical Product and Service Solutions). Teknik analisis data yang digunakan dalam penelitian adalah kuantitatif dan kualitatif. Hasil penelitian menunjukkan bahwa Kecemasan Matematika dan self-efficacy berpengaruh terhadap e- learning. Hubungan antara Kecemasan Matematika dan selfefficacy terhadap E-learning adalah sebesar 0,938. Kecemasan Matematika dan self-efficacy mempengaruhi $E$ learning sebesar $87,9 \%$.
\end{abstract}

Kata kunci: Kecemasan Matematika, Self-efficacy, E-Learning.

Copyright (c) 2021 Mega Kusuma Listyotami

$\triangle$ Corresponding author: Mega Kusuma Listyotami

Email Address: megakusumalistyotami@gmail.com (J1. Prof. Dr. Hamka No. 541A, Kota Baturaja, Indonesia)

Received 21 April 2021, Accepted 11 May 2021, Published 04 July 2021

\section{PENDAHULUAN}

Era pandemi pada tahun 2020-2021 mengharuskan untuk melaksanakan E-learning. E-learning dapat didefinisikan sebagai sebuah bentuk teknologi informasi yang diterapkan di bidang pendidikan dalam bentuk dunia maya (Hanum, 2013). Pembelajaran E-learning yang efektif adalah pembelajaran yang menggunakan beberapa hal yaitu tersedianya hardware, software, sumber listrik, dan sumberdaya manusia.

Selain itu, Sistem E-learning harus dapat: (1) Menyediakan konten yang bersifat teacher-centered yaitu konten instruksional yang bersifat prosedural, deklaratif serta terdefinisi dengan baik dan jelas; (2) Menyediakan konten yang bersifat learner-centered yaitu konten yang menyajikan hasil (outcomes) dari instruksional yang terfokus pada pengembangan kreatifitas dan memaksimalkan kemandirian; (3) Menyediakan contoh kerja (work example) pada material konten untuk mempermudah pemahaman dan 
memberikan kesempatan untuk berlatih; (4) Menambahkan konten berupa games edukatif sebagai media berlatih alat bantu pembuatan pertanyaan. Perbedaan Pembelajaran Tradisional dengan E-learning yaitu kelas ,tradisional ${ }^{e e}$, guru dianggap sebagai orang yang serba tahu dan ditugaskan untuk menyalurkan ilmu pengetahuan kepada pelajarnya. Sedangkan di dalam pembelajaran, E-learning' fokus utamanya adalah pelajar. Pelajar mandiri pada waktu tertentu dan bertanggung-jawab untuk pembelajarannya (Yazdi, 2012).

Dalam E-learning ada beberapa hal yang harus diperhatikan yaitu terkait kecemasan siswa dan efikasi diri siswa dalam belajar matematika secara E-learning. Aktivitas mahasiswa dalam pembelajaran matematika melibatkan proses berfikir untuk mencapai berbagai kompetensi, keterampilan, dan sikap.Faktor yang mungkin menghambat siswa dalam belajar matematika adalah karena faktor kecemasan mereka, kecemasan matematika berhubungan dengan perasaan tegang atau cemas siswa bekerja dengan angka atau memecahkan masalah dalam matematika (Guita dan Tan : 2018). Menurut Winarso dan Haqq (2019) ada hubungan yang signifikan antara kecemasan matematika dan kebahagiaan belajar.

Cooke, dkk. (2011) menyatakan bahwa kecemasan matematika seseorang dapat diidentifikasi dari 4 domain, yaitu mathematics knowledge/understanding, somatic, cognitive, dan attitude. Mathematics knowledge/understanding berkaitan dengan hal-hal seperti munculnya pikiran bahwa dirinya tidak cukup tahu tentang matematika. Somatic berkaitan dengan perubahan pada keadaan tubuh individu misalnya tubuh berkeringat atau jantung berdebar cepat. Cognitive berkaitan dengan perubahan pada kognitif seseorang ketika berhadapan dengan matematika, seperti tidak dapat berpikir jernih atau menjadi lupa halhal yang biasanya dapat ia ingat. Attitude berkaitan dengan sikap yang muncul ketika seseorang memiliki kecemasan matematika, misalnya ia tidak percaya diri untuk melakukan hal yang diminta atau enggan untuk melakukannya.

Kaitannya dengan efikasi diri adalah menurut Unlu, dkk (2017) individu dengan keyakinan selfefficacy rendah terhadap matematika dilaporkan tinggi tingkat kecemasan matematikanya. Bandura mendefinisikan self-efficacy sebagai kepercayaan seseorang terhadap kemampuannya untuk berorganisasi dan melakukan tindakan yang diperlukan untuk mencapai hasil yang diinginkan. self-efficacy merupakan keyakinan individu terhadap kemampuannya dalam melakukan sesuatu hal ketika berada dalam berbagai macam kondisi dengan berbagai keterampilan yang dimilikinya, untuk mencapai hasil yang diinginkan (Listyotami:2018). Aspek untuk mengukur self-efficacy menurut Noer (2012:805) adalah sebagai berikut: (1) Pencapaian kinerja, indikator kemampuan yang didasarkan kinerja pada pengalaman sebelumnya; (2) Pengalaman orang lain, Bukti yang didasarkan pada kompetensi dan perbandingan informatif dengan hasil yang dicapai orang lain; (3) Persuasi verbal, Mengacu pada umpan balik langsung/kata-kata dari guru atau orang yang lebih dewasa; (4) Indeks psikologis, Penilaian kemampuan, kekuatan dan kelemahan.

Zimerman dan Kitsantas dalam zimerman (2000:86) "found self-efficacy to be highly correlated with students". Zimerman dan Kitsantas menemukan bahwa self-efficacy berkorelasi tinggi dengan kemampuan siswa. Hal ini sesuai dengan pendapat Ayotolaa dan Adedejib (2009:956) "there is a strong positive relationship between mathematics self-efficacy and achievement in mathematics", ada hubungan 
positif yang kuat antara self-efficacy matematika dan prestasi dalam matematika. Diperkuat dengan hasil penelitian Soleymani dan Rekabdar (2016:19) "high positive self-efficacy has positive impact on mathematics achievement. In contrast, low self-efficacy may have negative impact on students' mathematics achievement". Self-efficacy yang positif tinggi memiliki dampak positif pada prestasi matematika, sebaliknya, rendahnya self-efficacy mungkin memiliki dampak negatif pada prestasi matematika siswa. Ditambahkan pula menurut Zarch (2006) self-efficacy dan kemampuan matematika siswa juga memiliki efek langsung terhadap kinerja matematika siswa. Oleh sebab itu akan dilakukan penelitian apakah dengan adanya E-learning, akan berpengaruh pada tingkat kecemasan matematika siswa dan self-efficacy diri siswa.

\section{METODE}

Penelitian ini menggunakan metode campuran dengan desain triangulasi. Triangulasi adalah desain penelitian satu fase, dimana peneliti mengimplementasikan metode kuantitatif dan kualitatif secara bersamaan dengan bobot yang seimbang. Penelitian dilakukan di Sekolah Tinggi Ilmu Ekonomi Dwi Sakti Baturaja pada bulan Februari 2021. Subjek penelitian ini adalah 30 orang mahasiswa semester VI pada kegiatan kokurikuler crash course dengan SPSS. Subjek penelitian dipilih karena mewakili data secara keseluruhan dipilih dari kemampuan mahasiswa tinggi, sedang, dan rendah.

Metode pengumpulan data yang digunakan dalam penelitian ini adalah dengan angket skala kecemasan matematika, angket self-efficacy, angket pembelajaran E- learning dan wawancara dengan menggunakan voice note. Untuk angket aspek kecemasan matematika adaptasi dari Cooke, dkk. (2011), angket aspek self-efficacy adaptasi dari Noer (2012), dan angket aspek E-learning. Dalam melakukan wawancara, peneliti dipandu dengan pedoman wawancara yang dikembangkan berdasarkan domain kecemasan matematika Cooke, dkk. (2011), self-efficacy adaptasi dari Noer (2012), dan angket aspek Elearning. Analisis data kuantitatif dan kualitatif dilakukan untuk memperoleh deskripsi kecemasan matematika dan self-efficacy pada mahasiswa.

\section{HASIL DAN DISKUSI}

Berdasarkan hasil analisis secara SPSS versi 20, hasil adalah sebagai berikut.

Tabel 1. Hasil Analisis Data

\begin{tabular}{|c|c|c|c|c|c|c|}
\hline \multirow{2}{*}{\multicolumn{2}{|c|}{ Model }} & \multicolumn{2}{|c|}{$\begin{array}{l}\text { Unstandardized } \\
\text { Coefficients }\end{array}$} & \multirow{2}{*}{$\begin{array}{c}\begin{array}{c}\text { Standardized } \\
\text { Coefficients }\end{array} \\
\text { Beta } \\
\end{array}$} & \multirow[t]{2}{*}{$\mathrm{t}$} & \multirow[t]{2}{*}{ Sig. } \\
\hline & & B & Std. Error & & & \\
\hline \multirow{3}{*}{1} & (Constant) & 3.087 & 1.237 & & 2.496 & .019 \\
\hline & MathematicsAnxiety & .517 & .107 & .571 & 4.855 & .000 \\
\hline & SelfEfficacy & .351 & .101 & .409 & 3.477 & .002 \\
\hline
\end{tabular}

Dari tabel 1, diperoleh persamaan regresi linear berganda: $\mathrm{Y}=3,087+0,517 \mathrm{X} 1+0,351 \mathrm{X} 2$. Nilai konstanta sebesar 3,087. Nilai tersebut menunjukkan bahwa apabila tidak ada Kecemasan Matematika dan 
self-efficacy maka E-learning akan senilai 3,087. Koefisien regresi untuk variable Kecemasan Matematika sebesar 0,517 artinya terjadi peningkatan positif dalam E-learning karena Kecemasan Matematika mahasiswa sebesar 0,517, model angket Kecemasan Matematika yang digunakan berupa anti Kecemasan Matematika. Koefisien regresi self-efficacy sebesar 0,351 artinya ada peningkatan positif terhadap $E$ learning karena factor self-efficacy yang meningkat.

Berdasarkan uji t, variable Kecemasan Matematika mempunyai t hitung $=4,855 ; 4,855>2,056$. Maka ada pengaruh secara parsial antara variable Kecemasan Matematika terhadap E-learning. Variable self-efficacy mempunyai t hitung $=3,477 ; 3,477>2,056$. Maka ada pengaruh secara parsial antara variable self-efficacy terhadap E-learning.

Hal ini sejalan dengan pendapat Unlu, dkk (2017) individu dengan keyakinan self-efficacy rendah terhadap matematika dilaporkan tinggi tingkat kecemasan matematikanya, sebaliknya individu dengan keyakinan self-efficacy tinggi terhadap matematika maka rendah tingkat kecemasan matematikanya. Selfefficacy yang tinggi membuat tingkat keberhasilan E-learning tinggi. Berikut tabel 2 tingkat Kecemasan Matematika dan self-efficacy terhadap E-learning.

Rendahnya self-efficacy menyebabkan tingginya tingkat kecemasan matematika yang berpengaruh pada hasil belajar siswa. Beberapa factor dalam E-learning seperti koneksi internet tempat siswa belajar juga mempengaruhi hasil belajar siswa. Hal ini sesuai dengan pendapat Auliya (2016:3) hasil penelitian menyatakan bahwa kecemasan matematika merupakan salah satu faktor yang memiliki hubungan negatif dengan prestasi belajar. Clute dan Hembree (Auliya, 2016) menemukan bahwa peserta didik yang memiliki tingkat kecemasan matematika yang tinggi memiliki prestasi belajar matematika yang rendah. Hasil penelitian Daneshamooz, Alamolhodaei, dan Darvishian (2012) juga menunjukkan bahwa kecemasan matematika berkorelasi negatif dengan kinerja matematika. Sejalan dengan itu, HellumAlexander (2010) dalam penelitiannya menemukan bahwa kecemasan matematika juga berpengaruh terhadap kemampuan matematis.

Ditambahkan oleh Hariani, dkk (2020:7) yang menyatakan bahwa pembelajaran jarak jauh dengan E-learning secara umum dapat memberikan pemahaman terhadap mahasiswa sama halnya dengan perkuliahan tatap muka secara konvensional, namun tingkat kesempatan terhadap pemahaman yang diperoleh menjadi tidak sama terhadap setiap mahasiswa tergantung terhadap baik atau buruk nya koneksi internet yang dimiliki masing masing mahasiswa, hal ini dikarenakan apabila mahasiswa memiliki koneksi terhadap aplikasi E-learning kurang baik maka kesempatan untuk mengikuti diskusi materi menjadi terhambat.

Tabel 2. Model Summary

\begin{tabular}{|l|r|r|r|r|}
\hline Model & \multicolumn{1}{|c|}{ R } & R Square & $\begin{array}{c}\text { Adjusted R } \\
\text { Square }\end{array}$ & $\begin{array}{c}\text { Std. Error of } \\
\text { the Estimate }\end{array}$ \\
\hline 1 & $.938^{\mathrm{a}}$ & .879 & .870 & 1.456 \\
\hline
\end{tabular}

a. Predictors: (Constant), Self-Efficacy, MathematicsAnxiety

b. Dependent Variable: E_Learning 
Berdasarkan tabel 2 model summary, didapatkan bahwa nilai korelasi adalah 0,938, nilai ini menunjukkan bahwa hubungan antara semua variable independent yaitu Kecemasan matematika dan selfefficacy dengan variable dependen yaitu E-learning adalah sangat kuat karena mendekati nilai 1. Koefisien determinasi adalah sebesar 0,879 atau 87,9\%. Nilai ini menunjukkan bahwa kontribusi semua variable independent yaitu Kecemasan matematika (Kecemasan Matematika) dan self-efficacy adalah sebesar $87,9 \%$ terhadap variable dependen E-learning, sementara 12,1\% merupakan kontribusi dari faktor-faktor lain yang tidak diteliti.

\section{KESIMPULAN}

Hasil penelitian menunjukkan bahwa Kecemasan Matematika dan self-efficacy berpengaruh terhadap e- learning. Hubungan antara Kecemasan Matematika dan self-efficacy terhadap E-learning adalah sebesar 0,938. Kecemasan Matematika dan self-efficacy mempengaruhi E-learning sebesar 87,9\%. Tingkat kecemasan matematika berbanding terbalik dengan tingkat self-efficacy siswa, siswa yang memiliki tingkat kecemasan matematika yang rendah akan mempunyai tingkat self-efficacy yang tinggi, sebaliknya siswa yang memiliki tingkat kecemasan matematika yang tinggi akan mempunyai tingkat selfefficacy yang rendah.

\section{REFERENSI}

Auliya, R. N. (2016). Kecemasan Matematika dan Pemahaman Matematis. Formatif: Jurnal Ilmiah Pendidikan MIPA, 6(1), 12-22. https://doi.org/10.30998/formatif.v6i1.748

Ayotola, A., \& Adedeji, T. (2009). The relationship between mathematics self-efficacy and achievement in mathematics. Procedia - Social and Behavioral Sciences, 1(1), 953-957. https://doi.org/10.1016/j.sbspro.2009.01.169

Cooke, A., Cavanagh, R., Hurst, C., \& Sparrow, L. (2011). Situational Effects Of Kecemasan Matematika In Pre-service Teacher Education. AARE 2011 Conference Proceedings, 1-14. http://aare.edu.au/11pap/papers_pdf/aarefinal00501.pdf

Daneshamooz, S., Alamolhodaei, H., \& Darvishian, S. (2012). Experimental Research about Effect of Mathematics Anxiety, Working Memory Capacity on Students' Mathematical Performance With Three Different Types of Learning Methods. ARPN Journal of Science and Technology, 2(4), 313321. http://www.ejournalofscience.org/Download_May_pdf_2.php

Hanum, N. S. (2013). Keefetifan E-learning sebagai media pembelajaran (studi evaluasi model pembelajaran E-learning SMK Telkom Sandhy Putra Purwokerto). Jurnal Pendidikan Vokasi, 3(1), 90-102. https://doi.org/10.21831/jpv.v3i1.1584

Hariani, P. P., \& Wastuti, S. N. Y. (2020). Pemanfaatan E-learning Pada Pembelajaran Jarak Jauh di Masa Pandemi Covid-19. Biblio Couns : Jurnal Kajian Konseling Dan Pendidikan, 3(1), 41-49. https://doi.org/10.30596/bibliocouns.v3i2.4656

Matematika, S. M. T. (2013). P -86. November 2012, 978-979. 
Mohammad Yazdi. (2012). E-learning sebagai Media Pembelajaran Interaktif Berbasis teknologi Informasi. Jurnal Ilmu Foristek, 2 (1)(1), 143-152.

Soleymani, B., \& Rekabdar, G. (2016). Soleymani \& Rekabdar. 2016. Relation between Math Selfefficacy and Mathematics Achievement with Control of Math Attitude.pdf. Applied Mathematics, 6(1), 16-19. https://doi.org/10.5923/j.am.20160601.03

Unlu, M., Ertekin, E., \& Dilmac, B. (2017). Predicting relationships between mathematics anxiety, mathematics teaching anxiety, self-efficacy beliefs towards mathematics and mathematics teaching. International Journal of Research in Education and Science (IJRES),3(2), 636645. DOI: 10.21890/ijres.328096

Winarso, W., \& Haqq, A. A. (2019). Psichological disposition of student; Kecemasan Matematika vesus happines learning on the level education. International Journal of Trends in Mathematics Education Research, 2(1), 19. https://doi.org/10.33122/ijtmer.v2i1.32

Zarch, M. K., \& Kadivar, P. (2006). The role of mathematics self-efficacy and mathematics ability in the structural model of mathematics performance. WSEAS Transactions on Mathematics, 5(6), 713-720. 